\title{
Analysis of the Village Head's Leadership Style in Cidokom Gunung Sindur Village, Bogor District
}

\author{
Gunartin \\ Universitas Pamulang \\ Email: gunartin9472@gmail.com
}

(Received: Februari 10-2020; revised: June 10-2020; published: June 30-2020)

\begin{abstract}
The purpose of the study is to analyze the leadership style of the Cidokom Village Head in carrying out his leadership mandated by the village community through general elections. The research method used is descriptive qualitative, with a direct observation approach to key informants to get accurate data. The researcher is an instrument in this study, therefore the researcher himself is digging information to get the data needed related to the leadership style of the head of Cidokom Village in carrying out village development. Data collection is done through observation, direct observation and interviews with village officials and the local village community to obtain data directly from the source. The results of the study can be described that village development tends to be static as seen from the absence of modern communication networks, public transportation has not been adequately available and high crime rates and slow service of bureaucracy. In terms of the government program that is driving independent village development, Cidokom Gunung Sindur Village, Bogor Regency still does not meet the government's expectations in efforts to accelerate village development. technological development.
\end{abstract}

Keywords: Leadership style; authority; acceleration of village development

\section{INTRODUCTION}

A leader's leadership is unique and can be inherited automatically. Each leader has certain characteristics that arise in different situations (Akib \& Dervish, 2015; Akib \& Salam, 2016; Pihie, Sadeghi, \& Elias, 2011; Thoha, 2014). Leadership in accordance with the state of the institution and the desires of employees will encourage increased employee performance in achieving the goals and objectives of the institution. In carrying out their activities, leaders have their own ways to influence and direct their employees, so they are expected to work together to achieve company goals through the implementation of specified work (Asrar-ul-Haq \& Kuchinke, 2016; Gemeda \& Lee, 2020; Huertas-Valdivia , Gallego-Burín, \& Lloréns-Montes, 2019).

According to (Hasibuan, 2011), leadership is someone who uses his authority and leadership to direct others and take responsibility for the work of that person in achieving a goal. (Sunyoto, 2012), argues that leadership is an organizational nature and leadership attitude of a leader to influence others is very decisive in achieving organizational goals. Being according (Handoko, 2011), that leadership is the ability possessed by a person to influence others to work towards goals and objectives.

A leader must at least be able to lead subordinates to achieve organizational goals, be able to handle relationships between employees, have good personal interaction, and have the ability 
76| Jurnal Ilmiah Ilmu Administrasi Publik: Jurnal Pemikiran dan Penelitian Administrasi Publik

Volume 1o Number 1, January- june 2020. Page 75-84

to be able to adjust to the situation (Irfan Ibrahim, 2018; Niswaty, Juniati, Dervish, Salam, \& Arhas, 2019). Leadership is the backbone of organizational development because without good leadership it will be difficult to achieve organizational goals. If a leader tries to influence the behavior of others, then that person needs to think about his leadership style. According to (Kartono, 2011) leadership style is everything in a person including habits, traits, personality and character which will be the difference between one leader with other leaders in dealing with others.

In carrying out village administration, a village head is assisted by the village government apparatus to exercise authority, rights and obligations as the leader of the village government as a form of performance implementation by organizing his own household which is the main executor and responsible in the fields of government, development and society as well as general government affairs including development, peace and public order in accordance with applicable laws and regulations. Also growing the attitude of mutual cooperation in the community as the main joint implementation of the village administration (Iskandar Ibrahim, 2019; Nasila \& Akib, 2014).

Cidokom village tends to be static, compared to the surrounding villages that have started to be literate in science and technology, of course this can not be separated from the leadership style of the Village Head who is the highest leader of the village. Cidokom village is led by a village head who is appointed through the electoral system every five years. Based on the results of the pre-research observations that have been carried out through observing the state of the village, the social status of the population, the economy of the community, the performance of village officials and village leaders, the researcher found many problems related to the leadership style of the village head. Where the village head tends to make decisions directly, village officials along with elements of village support are seen as not optimally carrying out their duties, youth organizations and non-governmental organizations have not shown their role in developing, advancing and developing villages in accordance with the times.

Based on the results of these observations, researchers assume village development requires a leader who can move all elements of the village to promote the village and develop rural communities from all sectors and economic resources, including education and training of youth through youth groups, women's empowerment and improvement rural community income by optimizing local potential and utilizing information technology. With the hope of being able to provide input to village heads and village officials in efforts to improve the quality of leadership, for village development and progress in accordance with the times.

\section{METHOD}

Research with a qualitative approach is a research method for conducting research on natural conditions, where the researcher as a key instrument (Sugiyono, 2016). Therefore this study uses a qualitative approach with the intention of researchers to understand social situations in depth. This study uses the object of Cidokom Village, Gunung Sindur Subdistrict, Bogor Regency because researchers see that Cidokom Village with its potential has time to carry out sustainable development to become an independent village.

The qualitative research sample is a resource person, participant or informant. In this 
study using primary data sources from the Village Head and the village secretary as key informants, with data collection techniques through observation, interviews and document literature. The researchers' consideration of using the village head and village secretary as key informants was based on the focus of the research who wanted to describe the leadership style of the village head in accelerating the development and development of Cidokom Gunung Sindur Village in Bogor Regency in order to obtain authentic data in accordance with the research objectives. Therefore, to facilitate data collection, researchers identify data and are classified into two namely; Primary data is direct data from research subjects in the form of verbal or verbal and subject behavior (research sources) relating to the relevance of competence (Sugiyono, 2008). Secondary data is data used to support primary data in the form of documents, photos and other records that can be used as data sources (Sugiyono, 2016). To obtain the data needed, in determining the size of the sample in this study using a purposive sampling method, namely the technique of sampling data sources with certain considerations. This particular consideration means that the chosen subject is considered to know the most information needed and expected or perhaps he is the ruler so that it will be easier for researchers to explore the social situation under study (Sugiyono \& Republik Indonesia, 2010)

Data analysis technique is describing what analysis techniques are used by researchers to analyze the data that has been collected (Sanusi, 2014). In this study a descriptive statistical analysis method is used, which is an analysis that is intended to explain data from one variable under study. In this method, descriptive is often used to describe the results of research data. Data reduction stage: data reduction is the process of selection, focusing, abstracting, transformation of rough data in the direct field, and continued at the time of data collection, thus data reduction begins when the researcher focuses the research area. The data presentation stage, which is a series of information organizations that allows research to be carried out. Presentation of data obtained by various types, networks, linkages of activities or tables. Conclusion drawing stage, namely in the collection of data, researchers must understand and respond to something that is studied directly in the field by arranging patterns of direction.

\section{RESULT AND DISCUSSION}

Cidomom Village is part of the area of Gunungsindur District, Bogor Regency, which wants to develop like other villages. Cidokom village that can be accessed from various directions such as: 1). From the east through the Old Market Ciampea, Batu Tulis Ciaruteun, Cidokom .: 2). From the South: Leuwi liang, Karehkel, Mekar Jaya (Kp Jengkol), Gobang Village, turn right Cidokom Village; and 3). From the North: Ciseeng, Putat Nutug, Gn Nyungcung Market, Rabak, Cibodas, after the Gobang market turn left it borders the area with: North side: Padurenan Village; Southern side: Warujaya Village; East side: Curug Village; West side: Cibinong Village.

Cidokom village which has a category of Madya Village has an area of 295 ha with a population of 8,434 people (Village Documents, 2019) and consists of 3 Dusun, 6 RW and 22 RT, led by a Village Head and assisted by village officials. Cidokom Village has been divided into 2 villages, namely: Cidokom Village and Mekar Jaya Village. Based on the December 2012 Pilkades elected as Mekar Jaya Village Head is Cecep M., S.Ag. While the Head of Cidokom Village (old) is H. Asep Nuryana, S.H., M.Pd.I. who ran his government ended in 2013 after twice the government through the Pilkades was replaced by the new Village Head, Mr. Sain 
78 | Jurnal Ilmiah Ilmu Administrasi Publik: Jurnal Pemikiran dan Penelitian Administrasi Publik Volume 1o Number 1, January- june 2020. Page 75-84

Saputra, S.E until now. Mr. Sain Saputra, S.E as the Head of Cidokom Village, Gunungsindur District, Bogor Regency is responsible and has the obligation to develop the village into an independent village so that it can prosper the community.

From the results of research by conducting interviews with key informants, in the work program plan of Cidokom Village, Gunungsindur Sub-district in the 2019 fiscal year, programs and activities are categorized into programs / activities / targets based on the load of the hallmark indicators of the implementation of the vision and mission of the Cidokom Village Government, sspect, focus and performance indicators and plans according to the field of village governance, the field of development, the field of society, and the field of community empowerment with reference to the Village Government Work Plan (RKPDesa) and the Village Medium Term Development Plan (RPJMDesa) in accordance with the village's authority, actually a work program from year to year It is well planned, but independent village development cannot be realized without the synergy of all elements of the village, namely the village head, village officials and the village community.

In the last 10 years development has continued to be carried out in stages, especially in the field of road infrastructure, both environmental roads and connecting roads between villages, said Sain Saputra, SE Head of Cidokom Village, Gunung Sindur Subdistrict, Bogor Regency, in his office during the data collection interview also expressed his gratitude that Since its inception as Head of Cidokom Village from 2013 until now the achievement of the realization of road infrastructure has reached $80 \%$ of the target set to reach $100 \%$ at the end of 2020. It was also conveyed that the source of funds came from budgetary assistance from the Central Government in the form of Village Funds also in support aid funds from the Provincial and District Governments and Aspirations from people's representatives.

Phase one and two infrastructure development has been carried out in the form of roads in several RTs and RWs as well as a Posyandu Unit (Integrated Service Post) in RT 03 RW 01, equitable distribution of development in each Dusun and RT, RW environment is realized in stages according to the results of the Dusun Consultation and RKPDES, whereby each Environmental Management and Village Head can propose development in their respective regions, additional exposure from Mr. Sain. Every implementation of infrastructure development involves all elements of the community in the sense of labor-intensive and budget transparency, also supported by community support that is very conducive. . Specifically for health facilities, Cidokom Village has 6 Posyandus and another unit is still in the process of being built, so there are 7 Posyandu units in 6 RWs, supported by cadres who have been able to cover providing services as medical staff besides village midwives, additionally from Mr. Sain.

From the results of interviews with the Secretary of the Cidokom Village also obtained data information that the preparation of human resources has also been carried out, especially for people who are professionals as farmers and catfish cultivation practitioners have collaborated with one of the Private Universities. at least the villagers can have the knowledge to improve the economy by farming, raising livestock or fish farming. One of the factors in the development of various sectors can be carried out by the attention of the regency government and related agencies. Other efforts in enhancing the development of Cidokom Village The village head also maximizes the role and function of the Village Owned Enterprises (Bumdes) for the welfare of the citizens, especially to provide access to capital for villagers so that they do 
not depend on and get entangled in a mobile bank (daily bank). expected to provide alternative solutions to financial problems faced by citizens.

The village head also added that during his leadership he had succeeded in pioneering the construction of a bridge over the Cisadane River, which connects Cidokom village with Cibungbulang and Ciampea sub-districts. so that the isolation area can be opened. This is done to open access to Cidokom Village more broadly so that development will be easier to carry out. Development carried out oriented to the environment, this can be realized that in Cidokom Village there are no industries that have a negative impact on the environment, even directed to environmental preservation. The development of the tourism sector is also being increased for regional income sources such as the Long Horn Village (Less Sugar), recreation areas and "Bike Trial" facilities, where on Sundays / holidays there are many tourists from Jakarta and surrounding areas. in the Cidokom hilly region, which borders the village of Mekar Jaya, which has a good view towards the horizons of Tangerang and Jakarta.

In carrying out the performance of village administration, the leadership certainly has a plan for a program that will be carried out both within 1 (one) year and within 6 (six) years while holding the position of Village Head. Whereas plans and work programs in the field of village administration for a period of 1 (one) fiscal year generally fulfill work programs, namely: making Village Law Products that refer to the provisions of the applicable laws and regulations to become one of the work references in the field of village governance; carry out a recapitulation of the development of the population growth rate; carry out land orderly chess; carry out government management of the recruitment of village apparatus and Village Government Institutions based on needs and applicable provisions; increasing the administration of peace and order in the region and the environment as well as being alert to security disturbances; carry out coaching enhancement of Human Resources for the Village Government Institutions and Village Community Institutions.

From the planned activities that have been programmed, in the context of achieving the goals and objectives of development in the field of village governance, the village leadership certainly will not be able to carry out their own tasks without the synergy of the community and related agencies / agencies. Development planning and development realization have indeed been carried out in part, but have not shown significant results according to the development objectives of becoming an independent village in the welfare of the community.

After analyzing the results of the research, from the village development programs that have been carried out to achieve the development goals there are a number of things that have not been achieved to the fullest extent, this is based on the acquisition of supporting data such as the number of people in terms of education and socioeconomic status of the livelihoods. where this still shows the low level of education in Cidokom Village and of course also the low quality of human resources which is shown in the high number of residents with household management status. The following is a demographic of the population of Cidokom Village, Gunungsindur District, Bogor Regency. 
80| Jurnal Ilmiah Ilmu Administrasi Publik: Jurnal Pemikiran dan Penelitian Administrasi Publik Volume 1o Number 1, January- june 2020. Page 75-84

Table. 1

Population According to Gender

\begin{tabular}{llll}
\hline No & Description & Amount & information \\
\hline 1 & Male $(\mathrm{M})$ & 4.266 & Soul \\
2 & Female $(\mathrm{F})$ & 4.168 & Soul \\
5 & Number of Souls $(\mathrm{M}+\mathrm{F})$ & $\mathbf{8 . 4 3 4}$ & Soul \\
\hline
\end{tabular}

Source: Cidokom Village Office Document 2019

Whereas the population according to their level of education and livelihood is as follows:

Table. 2

Population Statistics According to Education Level

\begin{tabular}{llll}
\hline No & \multicolumn{1}{c}{ Level of education } & Amount & information \\
& & & \\
\hline 1. & Not yet / Not in school & 417 & Person \\
2. & PAUD / TK & 509 & Person \\
3. & Not finished elementary school / equivalent & 2.222 & Person \\
4. & Graduated from elementary school / & 2.880 & Person \\
& $\begin{array}{l}\text { equivalent } \\
\text { 5. }\end{array}$ & Graduated from junior high school / & Person \\
& equivalent & & \\
6. & Graduated from high school / equivalent & 909 & Person \\
7. & Graduated from Academy / Sarmud / D-1, D- & 26 & Person \\
& 2, and D-3 & & \\
8. & Graduated from University / Bachelor & 48 & Person \\
9. & Graduated from University / S-2 & 8 & Person \\
10 & Graduated from University / Doctoral degree & - & Person \\
11 & TPA education & & Person \\
12 & Boarding School Education & & Person \\
& Total & $\mathbf{8 . 4 3 4}$ & Person \\
\hline
\end{tabular}

Source: Cidokom Village Office Document 2019

From the data obtained based on the level of education above, it shows that the portion of elementary school graduates is $34.15 \%$, junior high school graduates are $16.34 \%$ and high school graduates are $16.78 \%$. This reflects that primary school graduates are still dominant compared to higher level graduates. For an era like now, graduates / elementary school graduates can no longer meet the qualifications of job vacancies, which will only get the opportunity to become a housekeeper, household system or lower level employees. 
Gunartin; Analysis of the Village Head's Leadership Style Style ... 81

Table. 3

Population According to Livelihood

\begin{tabular}{llr}
\hline No & \multicolumn{1}{c}{ Level of education } & Amount (persons) \\
\hline 1. & Farmers / Farmers & 114 \\
2. & Trader & 50 \\
3. & Government employees & 42 \\
4. & Indonesian National Army / Indonesian Police & 18 \\
5. & Retired / Retired & 10 \\
6. & Taking care of household & 1674 \\
7. & General employees & 1329 \\
8. & Freelancers & 215 \\
9. & Craftsman & 50 \\
10. & Builder & 150 \\
11. & Tailor & 97 \\
12. & Welder & 59 \\
13. & Motorcycle taxis driver & 50 \\
14. & Workshop & 25 \\
15. & Transportation Driver & 35 \\
16. & Other / not yet active / not yet productive & 4516 \\
& Amount & $\mathbf{8 4 3 4}$ \\
\hline
\end{tabular}

Source: Cidokom Village Office Document 2019

While based on livelihoods, the data obtained showed the highest percentage of household administrators, namely $19.85 \%$ of those who had moderate work activities or those who were not yet productive, showed a figure of $53.54 \%$. From the data, there is still a need to pay special attention to improving the quality of human resources in order to go to an independent village. The success of village development is certainly influenced by the leadership style of the Village Head as the number one person in village governance. Becoming a Village Head is not enough just to rely on his power in carrying out village governance, but a figure that is able to move all elements of the village to jointly build a village in a sustainable manner so that in the future will become an independent village that does not depend on other villages or district governments local.

In addition to the data above, Cidokom Village still shows that development has not been maximized, this can be demonstrated by some damaged infrastructure such as the entrance of the Tangerang Selatan - Bogor provincial highway, frequent outages without clear schedules, unstable communication signals and community activities tend to be massive, so it appears that many people who have not been working.

The slightly closed leadership style did indeed impact the lack of use of the village's structural community. The potential of the community which should be the strength of the village to carry out development and become a developed and independent village, because of the lack of open and dominant village governance such as a dynasty limited to the family and relatives in office, this will reduce the professionalism of work. It will be difficult to get constructive input and criticism, let alone make changes along with the development of communication and information technology. 


\section{2 | Jurnal Ilmiah Ilmu Administrasi Publik: Jurnal Pemikiran dan Penelitian Administrasi Publik Volume 1o Number 1, January- june 2020. Page 75-84}

This is supported by previous research which states that development strategies can be carried out with approaches that guarantee ecological balance and economic growth with integrated and sustainable and community-based planning, supported by infrastructure and several policies such as cross-border trade policies (Gevisioner, Build, \& Karyanti , 2013). Also supported by the results of research (Syahza, 2013)), that rural development must be carried out with an approach that is appropriate to its nature and characteristics. Rural development must follow four major efforts, which are interrelated and constitute the main strategies of rural development, namely: empowering the economy of rural communities, improving the quality of rural human resources, infrastructure development in rural areas, and building rural institutions both formal and informal. The institutionalization needed by rural areas is the creation of good services especially to spur the rural economy for the creation of prosperous and independent village communities.

\section{CONCLUSION}

Cidokom Gunung Sindur Bogor village development has been carried out according to development planning, but to accelerate development it still needs synergy from all elements of the community, especially the Village Head as the motor driving element of the village to carry out village development into an independent village. The Village Head's leadership style greatly influences the success of the development goals. It takes a village head who has a high commitment and dedication to build his village to become a developed and independent village. In general, there are still many village development plans that have not been implemented optimally such as improving the quality of human resources, improving infrastructure facilities and infrastructure and changing the community paradigm that education is important.

\section{REFERENCES}

Akib, H., \& Darwis, M. (2015). Pengaruh Gaya Kepemimpinan Transformasional Kepala Sekolah Terhadap Kinerja Guru Pada SMK Negeri 1 Bungoro Kabupaten Pangkep. Jurnal Office, 1(1), 80-87.

Akib, H., \& Salam, R. (2016). Analisis Kualitas Pelayanan Publik Berbasis Importance Performance Analysis (IPA) pada Kecamatan Kota Makassar. Jurnal Ilmiah Scientific Pinisi.

Asrar-ul-Haq, M., \& Kuchinke, K. P. (2016). Impact of leadership styles on employees' attitude towards their leader and performance: Empirical evidence from Pakistani banks. Future Business Journal, 2(1), 54-64. https://doi.org/https://doi.org/10.1016/j.fbj.2016.05.002

Gemeda, H. K., \& Lee, J. (2020). Leadership styles, work engagement and outcomes among information and communications technology professionals: A cross-national study. Heliyon, 6(4), e03699. https://doi.org/https://doi.org/10.1016/j.heliyon.2020.e03699

Gevisioner, G., Bangun, R., \& Karyanti, K. (2013). Strategi Pembangunan Berbasis Masyarakat 
di Kecamatan Perbatasan Negara di Provinsi Riau. Jurnal Bina Praja: Journal of Home Affairs Governance, 5(1), 53-62.

Handoko, T. H. (2011). Manajemen Personalia dan Sumber Daya Manusia. Pengantar Manajemen.

Hasibuan, M. S. P. (2011). Manajemen Sumber Daya Manusia. Edisi Revisi Jakarta: Bumi Aksara.

Huertas-Valdivia, I., Gallego-Burín, A. R., \& Lloréns-Montes, F. J. (2019). Effects of different leadership styles on hospitality workers. Tourism Management, 71, 402-420. https://doi.org/https://doi.org/10.1016/j.tourman.2018.10.027

Ibrahim, Irfan. (2018). The Effect of New Pattern of Level IV Leadership Training and Education Policy Implementation on Leadership Competence of Supervisory Officials in Gorontalo Provincial Government. Jurnal Ilmiah Ilmu Administrasi Publik, 8(2), 165-172.

Ibrahim, Iskandar. (2019). Analysis of Management of Village Fund Allocation (ADD) in Pohuwato Regency. Jurnal Ad'ministrare, 6(1), 25-34.

Kartono, K. (2011). Pemimpin dan Kepemimpinan. Jakarta: Rajawali Grafindo Perkasa.

Nasila, J. W., \& Akib, H. (2014). Participative leadership of village head based local wisdom" H4" in district. Suwawa, Bolango Bone Regency, Gorontalo province Indonesia. Global Journal of Business, Economics and Management, 4(1), 29-36.

Niswaty, R., Juniati, F., Darwis, M., Salam, R., \& Arhas, S. H. (2019). The Effectiveness of Leadership Functions Implementation in The Makassar Departement of Manpower. JPBM (Jurnal Pendidikan Bisnis Dan Manajemen), 5(1), 1-10.

Pihie, Z. A. L., Sadeghi, A., \& Elias, H. (2011). Analysis of Head of Departments Leadership Styles: Implication for Improving Research University Management Practices. Procedia Social and Behavioral Sciences, 29, 1081-1090. https://doi.org/https://doi.org/10.1016/j.sbspro.2011.11.341

Sanusi, A. (2014). Teknik Pengumpulan Data dan Instrumen Penelitian. Metodologi Penelitian.

Sugiyono. (2008). Metode Penelitian Kuatintatif, Kualitatif dan R\&D. In Alfabeta. https://doi.org/2008

Sugiyono. (2016). Memahami Penelitian Kualitatif. Bandung: Alfabeta.

Sugiyono, \& Republik Indonesia. Metode Penelitian Kuantitatif \& kualitatif., Journal of Experimental Psychology: General § (2010).

Sunyoto, D. (2012). Manajemen Sumber Daya Manusia. Yogyakarta: CAPS (Center Of Academic Publishing Service).

Syahza, A. (2013). Strategi Pengembangan Daerah Tertinggal dalam Upaya Percepatan Pembangunan Ekonomi Pedesaan.

Thoha, M. (2014). Kepemimpinan dalam Manajemen. Jakarta: PT RajaGrafindo Persada. 
84 Jurnal Ilmiah Ilmu Administrasi Publik: Jurnal Pemikiran dan Penelitian Administrasi Publik Volume 1o Number 1, January- june 2020. Page 75-84 